\title{
Social and economic issues of farm produce from urban waste water irrigation
}

\author{
S. K. Tripathi \& B. Chintamanie \\ Department of Water Resources Development and Management, \\ Indian Institute of Technology, India
}

\begin{abstract}
The use of urban wastewater in agriculture and vegetable production is receiving renewed attention with the increasing scarcity of freshwater resources in many parts of the country. In many cities the wastewater used for irrigation is often inadequately treated. Uttar Pradesh, in India, produces about five thousand tonnes of vegetables annually and most of them are sold in large cities. Most of the rainfall received is during June to September and the rest of the year the crops need irrigation. A survey was conducted and it was found that tomatoes, eggplant, cauliflower, cabbages, carrot and leafy vegetables are grown using urban waste water. The cropping systems are variable according to available manpower, size of holding, access to wastewater, socio-economic condition, proximity to markets and access to roads, etc. The study found that most of such farmers were prone to stomach disorders. Developing a programme to aid a safe production system is felt to promote safer agro produce. The living and working conditions of farmers in a waste water use environment in India needs the attention of Governments in improving their socio economic conditions and undertake technological research to improve the quality of farm produce in the interest of the public at large.
\end{abstract}

Keywords: socioeconomic, farm produce, urban, wastewater, irrigation.

\section{Introduction}

The use of urban wastewater in agriculture is a centuries-old practice that is receiving renewed attention with the increasing scarcity of freshwater resources in many arid and semi-arid regions. Driven by rapid urbanization and growing wastewater volumes, wastewater is widely used as a low-cost alternative to 
conventional irrigation water; it supports livelihoods and generates considerable value in urban and peri-urban agriculture, despite the health and environmental risks associated with this practice.

As both industrialization and population continue to increase, the availability of freshwater decreases and wastewater becomes an important resource of planning. In India, because of urbanization, wastewater irrigation is increasingly being used for all crops, e.g., vegetables, fruits, cereals, flowers and fodder. However, the uncontrolled use of wastewater in agriculture has important health implications for farmers, families and communities located in wastewaterirrigated areas. Negative impacts on the health of the users of produce from the areas using untreated or inadequately treated wastewater are well documented in many reports.

Less attention has however been paid on the social and economic issues of the crop growers' use of wastewater in agriculture. This paper provides an overview of the socioeconomic problems of farmers using wastewater in agriculture in India.

\section{Background}

Worldwide, it is estimated that about $18 \%$ of cropland is irrigated, producing about $40 \%$ of all food (Gleick [1]). A significant portion of irrigation water is wastewater. At least 20 million ha in 50 countries are irrigated with raw or partially treated wastewater. It is estimated that one tenth or more of the world's population consumes foods produced on land irrigated with wastewater. Wastewater and excreta are also used in urban agriculture. A high proportion of the fresh vegetables sold in many cities, particularly in less-developed countries are grown in urban and peri-urban areas. More than $60 \%$ of the vegetables consumed in the city are grown in urban areas in Dakar and Senegal, and use a mixture of groundwater and untreated wastewater (Faruqui et al. [2]).

In many developing countries, wastewater used for irrigation is often inadequately treated. The estimate shows that the median percentage of wastewater treated by effective treatment plants is 35\% in Asia, $14 \%$ in Latin America and the Caribbean, $90 \%$ in North America and 66\% in Europe (WHO/UNICEF [3]).

Uttar Pradesh, often referred to as UP, is a state located in the northern part of India. With a population of over 190 million people, it is India's most densely inhabited state. With an area of $243,286 \mathrm{~km}^{2}$, Uttar Pradesh covers a large part of the highly fertile upper Gangetic plain where the major economic activity is agriculture; more than $66 \%$ of the people are engaged in agriculture. This state produces $20.4 \%$ of the total food grains in the country, and approximately 9.5 thousand tonnes of fruits and 25.1 thousand tonnes of vegetables are grown annually (EIS UP [4]). On average, UP receives about $950 \mathrm{~mm}$ rainfall annually. In the western parts of the State it averages around $950 \mathrm{~mm}$ while in the east it averages around $1100 \mathrm{~mm}$. About 90 percent of the rainfall occurs during the southwest monsoon, lasting about 4 months from June to September. While most 
of the rainfall is concentrated during this four-month period, floods and droughts are a recurring problem and cause heavy damage to crops, life, and property.

This threatens the food security of the region. Since it is convenient and reliable, many farmers in the vicinity of cities use untreated wastewater for irrigating their crops.

\section{Urban agriculture}

Agricultural practice followed in and around cities is called urban agriculture. This is predominated by the cultivation of vegetables. In Uttar Pradesh, the vegetable cultivation centers on a narrow fertile urban belt of 688,000 ha with an annual output of more than 13,850,000 tonnes as shown in Figure 1.

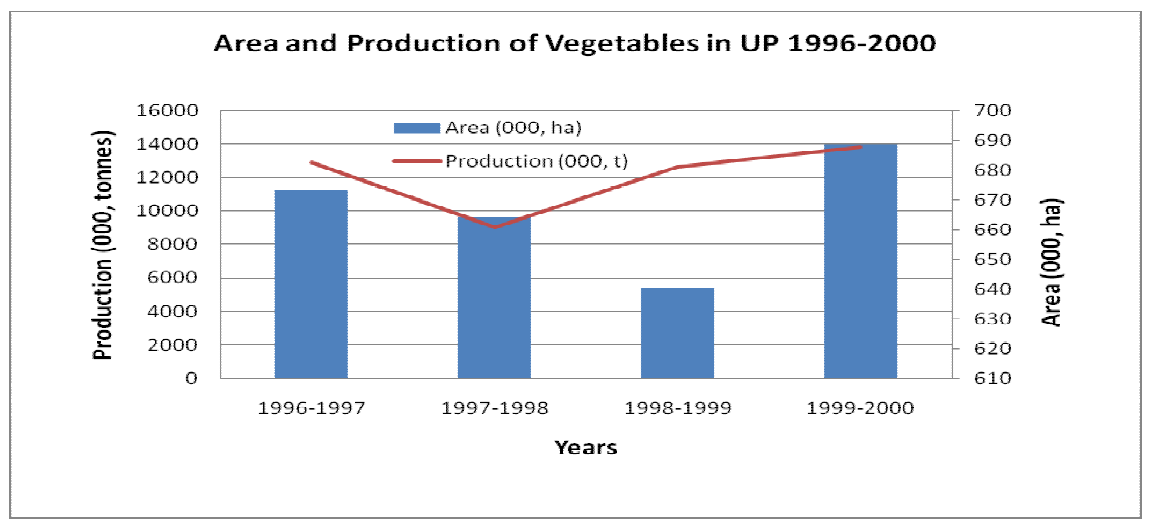

Figure 1: Area and production of vegetables in UP - 1996-2000 data: Indian Horticulture Database, 2001.

The area dedicated to cultivation of vegetable includes both normal agricultural land and river bed lands. Most of the rivers in North India carry heavily polluted water waste water during non monsoon season. This is pumped by river bed farmers to irrigate their vegetable crops. They also record very high yields and good looking produce. Cost of production of such crops is low because fertilizer application is rarely required. The lift head of water is hardly 12 metres. Therefore the cost of cultivation of such crops is very low and produce is cheap in the market. The main vegetable crops grown are tomatoes, eggplant, cauliflower, cabbage, onions, radish, carrot, cucumbers and leafy vegetables. While some fruits are also cultivated using waste water but vegetables are preferred over them because they grow faster and give quick return.

\section{Irrigation sources}

Farmers use untreated wastewater depending on access to source. In most cases, farmers pump directly into their field from tube wells or from effluent streams or use hand held buckets. Wastewater either drains naturally from broken pipes, or 
Table 1: $\quad$ Pollution class of river streams in India. Source: (Anon [5]).

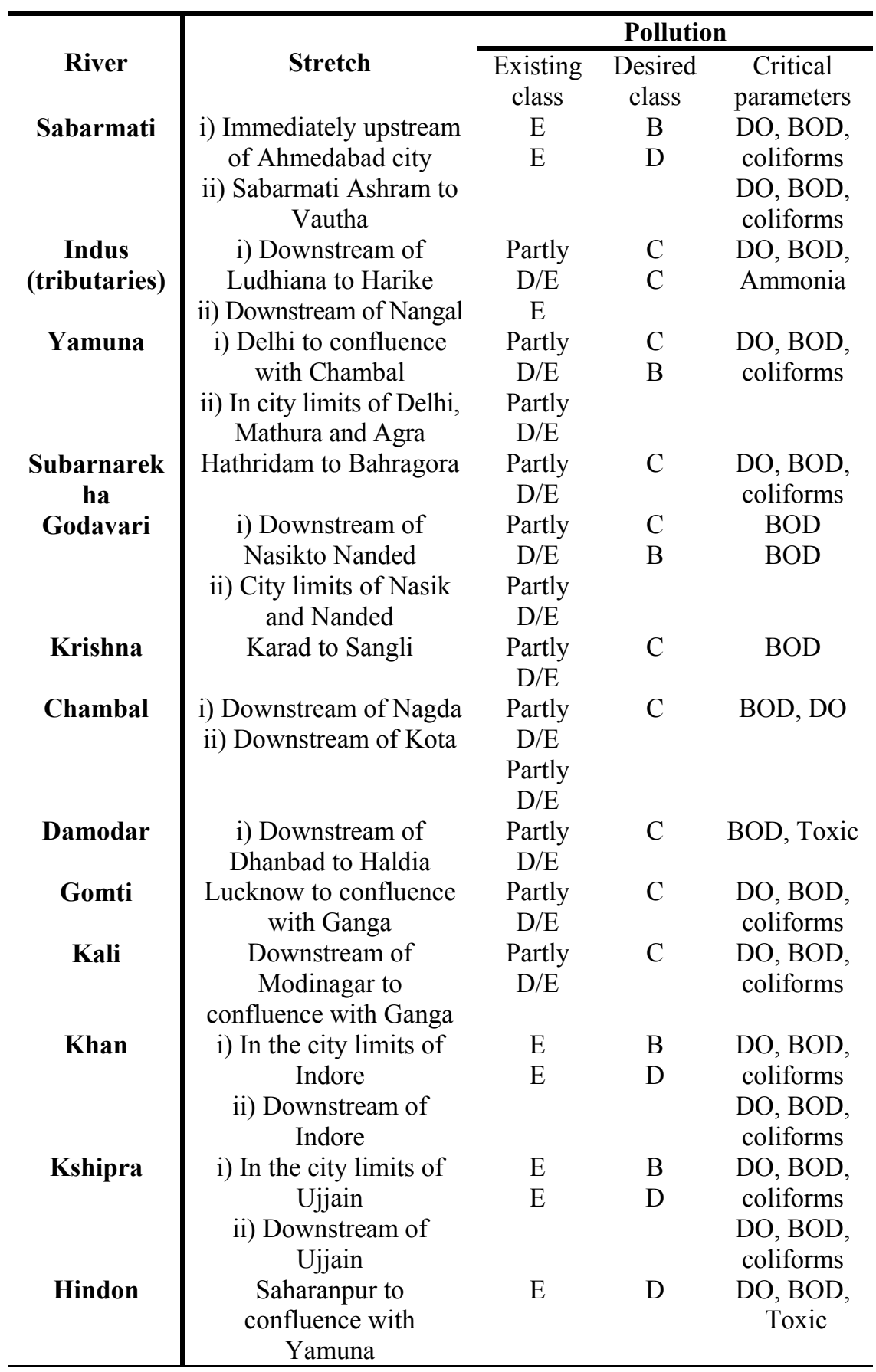


is directed by a channel into a depression from where it is collected. Some farmers have even installed centrifugal or mono block electric pumps to lift waste water for irrigation. The Ministry of Environment and Forest, Govt. of India, taking into account the pollution level, has rated most of the river streams as Class $\mathrm{C}, \mathrm{D}$ and $\mathrm{E}$ as shown in the Table 1 . Criteria adopted to classify rivers based on their pollution level of water are given in Table 2.

Table 2: Criteria used to classify rivers based on their pollution level. Source: (IWACO [6]).

\begin{tabular}{|cccccc|}
\hline Criterion & $\begin{array}{c}\text { Class } \\
\text { A }\end{array}$ & $\begin{array}{c}\text { Class } \\
\text { B }\end{array}$ & $\begin{array}{c}\text { Class } \\
\text { C }\end{array}$ & $\begin{array}{c}\text { Class } \\
\text { D }\end{array}$ & $\begin{array}{c}\text { Class } \\
\mathbf{E}\end{array}$ \\
\hline DO (mg/l) minimum & 6 & 5 & 4 & 4 & \\
\hline BOD (mg/l) maximum & 2 & 3 & 3 & & \\
\hline $\begin{array}{c}\text { Total coliforms count (MPN/100 } \\
\text { ml) maximum }\end{array}$ & 50 & 500 & 5,000 & & \\
\hline $\mathbf{p H}$ & $6.5-$ & $6.5-$ & 6.9 & $6.5-$ & $6.5-$ \\
& 8.5 & 8.5 & & 8.5 & 8.5 \\
\hline $\begin{array}{c}\text { Conductivity (micro mho/cm } \\
\text { maximum }\end{array}$ & & & & & 2,250 \\
\hline $\begin{array}{c}\text { Sodium absorption ration } \\
\text { maximum (SAR) }\end{array}$ & & & & & 26 \\
\hline Boron (mg/l) maximum & & & & 2 \\
\hline
\end{tabular}

Note : DO : dissolved oxygen

BOD : biochemical oxygen demand

The total coliform counts are the indicator of pathogenicity of water. As per the standard fixed by WHO, MPN count far exceeding the $1000 \mathrm{C} / 100 \mathrm{ml}$ of water although harmful to human health is not restricted from irrigation. Furthermore, such poor quality of raw wastewater could have contained the larvae, eggs, or cysts of several protozoa or worms - above the WHO standard. Water samples (analyzed for bacteriological and physicochemical parameters) from rivers in UP contained $>50$ coliforms $/ 100 \mathrm{ml},>50$ thermotolerant (faecal) coliforms $/ 100 \mathrm{ml}$ as well as the content of iron and manganese was reported above the maximum permissible limits (Pathak et al. [7]). Farmers, while using such contaminated water for irrigation, are vulnerable to their health risks. Many farmers have made their dwellings in the centre of their farm and live in a very unhygienic condition. Children are more prone to unhygienic condition and are required to frequently visit the health centers and spend quite a good part of their earnings on medical treatments only. Thus such farmers find it difficult to rise above the poverty line.

\section{Crop productivity and economic return}

The use of wastewater for crop production has been practiced for several centuries in the world in one form or another. There are agronomic and economic 
benefits of wastewater use in agriculture. Irrigation with wastewater reduces the pressure of irrigation on fresh water and helps conserve natural resources as the fertilizer value of many wastewaters is very high. A typical wastewater effluent could supply all the nitrogen and much of the phosphorus and potassium that are normally required for crop production (FAO [8]). In addition, micronutrients and organic matter also provide additional benefits.

Depending on the growth stage of the crops, about $15 \mathrm{~mm} /$ day of wastewater for irrigation is required in tropical to sub tropical climate. The vigorous plant growths resulting from the richness of the nutrients in the wastewater generally require more water. The waste water also adds organic matter in the soil that improves water-holding capacity of light soils. The general observation reveals that vegetables, especially leafy vegetables, are more responsive to waste water irrigation than other crops. Favorable response of lime application to fields and vegetable crops in waste water irrigated non acidic soils.

The results also show that in the case of leafy vegetables the wastewater irrigation promotes growth and is available for early harvest. Given the fact that the usual growing period of a leafy vegetable is from November to April, irrigated by potable water and record three cuttings, but records 5-6 cutting when irrigated by waste water. Such vegetables are more succulent therefore their perish ability is very high. For all of the above reasons, the farmers interviewed in different wastewater sites had reported a higher annual return.

\section{Health and environmental effects}

\subsection{Health effects}

Many farmers suffer from ill health because of their direct contact with wastewater; the lack of protective wear makes them vulnerable to infection by parasites, transmitted either orally or through the skin. At places where only wastewater is available, most of farmers were infected with intestinal parasites. At places where water sources are mixed (higher class); the level of infection was lower. The most common parasites found were Ascaris ascaris (roundworm) and Strongyloides stercoraltis (threadworm). The eggs or larvae of these worms, which live in the intestine, are passed through the faeces. In the case of roundworm, re-infection is then oral, by ingesting food contaminated by the infective eggs. Threadworm, like hookworm infects by penetrating the skin of the feet or hands of farmers working in fields irrigated with wastewater.

A high density of Plasmodium falciparum, the parasite that causes malaria, was found in some farmers. Malaria could be endemic to the area, with many Anopheles mosquitoes present. Farmer's families by and large were frequently exposed to gastroenteritis problems causing diarrhea, dysentery, acidity and many problems related to their stomach.

\subsection{Environmental effects}

Plants growing in a polluted environment can accumulate the toxic metals at high concentration causing serious risk to human health when consumed. The 
understanding of the behavior of heavy metal in soil-plant system seems to be particularly significant. The sources of heavy metal in plants are their growth media (soil and water) from which heavy metals are taken up by roots or foliage. Although some heavy metals such as $\mathrm{Cu}, \mathrm{Zn}, \mathrm{Mn}$, and $\mathrm{Fe}$ are essential in plant nutrition, many heavy metals do not play any significant role in the plants physiology. Plants growing in a polluted environment can accumulate the toxic metals i.e. $\mathrm{Pb}, \mathrm{Cr}, \mathrm{Cd}, \mathrm{Ni}$ etc at high concentrations causing serious risk to human health when consumed (Vousta et al [9]).

The uncontrolled input of heavy metals in soils is totally undesirable because once it is accumulated in the soil; the metals are very difficult to remove (Smith [10]). Subsequent problems may be toxicity to the plant growing on the contaminated soil and uptake by the plants resulting in high metals levels in plant tissues. Since one of the main sources of these heavy metals contamination includes discharge of metal polluted wastewater to land, attempts have been made by various researches to find more effective means of eliminating, controlling or managing these heavy metal discharges from industrial effluent and sewage water at the Sewerage Treatment Plant level itself. Since most industries bypass the regulations on treatment and management of effluents before discharge they still find their way into agricultural fields.

\section{Farming profile}

Almost $85 \%$ of the surveyed farmers were men, mostly above 35 years old, and the primary wage earners in their families. Some female family members do help during the harvests and act as intermediaries, selling crops in the market. For most it is their main occupation. All groups were represented and the practice is not restricted to the poorest groups. The farming systems differ widely, showing wide variability in plot size, intensity, and profit, and depend on various factors, including access to water or wastewater, socio-economic level, proximity to markets, land tenure, soil quality, and whether or not farming is the principal occupation.

Crops are largely intended for the market, but a small amount is for home consumption. The researchers were challenged in trying to make estimates of the economic value of this production, because while the farmers interviewed stated they earn reasonable profits, they were either unable or unwilling to give precise figures. It was difficult to assess input costs due to the informal nature of urban gardening and the reticence of some farmers to respond to surveys.

\section{Sustainable urban production}

All wastewater contains pathogens and these pathogens do pose a risk not only to the farmers and their families but also to the society. The water is the means that allows an infectious pathogen to move to a new host through food cycle. The intermediate step in this process is crop production which can provide a route of infection. 
There are two approaches to developing a regulatory programme for health protection. The first is to focus on lowering the risk from the water. This is normally done by wastewater treatment or treatment and disinfection. Where the treated water does not meet health protection standards for unrestricted irrigation, the focal point for risk reduction, shifts to the point of water use (irrigation). Here agricultural restrictions can lower the potential health risks. The point of water use is usually where the route of infection shifts to the soil and crop; therefore, these become the primary focus of management or regulatory strategies.

There are numerous agronomic practices that can assist in lowering the risk from wastewater use but most of these are site specific that are normally made by the farmer to increase agricultural production and not to lower the overall disease infection risk. Farmers cannot be expected to implement a programme that focuses on individual cultural practices since his goal is production and not the research. Any regulatory approach must be institutionalized and have to focus on the type of crops grown.

Adopting a crop restriction programme as a means of health protection where wastewater is used for irrigation requires a strong political will. It also requires the machinery to monitor and control compliance with regulations and to enforce them. In reality, if the wastewater is not used in a defined and restricted area and the use of that water is not centrally controlled, the enforcement of a crop restriction programme at the field level will not be easy to accomplish.

The key to effectiveness of any programme is the farmer. It involves ensuring that there is a strong market for the crops allowed for production and high-risk on the restricted crops. Educating farmers on such issues can help easing the problem.

Developing a programme to promote safe production areas is another alternative to crop restrictions and can be done in three-phases. The first phase is to develop a sound information base (water quality monitoring phase) that can be used to evaluate the existing levels of contamination (water quality) in the water being used for production. This includes selection of contamination indicators, establishing field sampling methods, defining acceptable laboratory analytical methods, selecting participating laboratories, selecting the field monitoring sites and conducting a field water quality monitoring programme.

The second phase involves evaluating the water quality data collected in the first phase and developing procedures to assess the levels of contamination (data analysis and evaluation phase) and define safe production areas. The database could also be used as a basis to control or regulate contaminated water use in vegetable or other high-risk production areas.

The third and final phase of developing a programme to promote safe production areas is developing mechanisms to regulate the use of contaminated water on vegetable or other high-risk crops (crop or water certification phase).

The success of subsequent phases will depend upon the successful completion of the previous phase. 


\section{Conclusion}

Urban waste water irrigation in the production of vegetables around cities has many social and economic issues with farm produce and producers. River streams are heavily polluted and farmers are using that water on their fields. Farmers and their family members are exposed to health risk therefore need social and economic insurance. Farmers prefer using wastewater to freshwater for irrigation, as it is free, easily accessible and crops are very healthy giving a good return. Most of the return obtained from their small holding or leased holdings are lost in health care. Most of such farmers are plagued with intestinal parasites. Produce of such areas poses a significant public health risk. Technologies of safe produce to safeguard the interest of produce, producer and user are essentially felt.

\section{References}

[1] Gleick, Peter H.: (2000) The Changing Water Paradigm A Look at Twentyfirst Century Water Resources Development International Water Resources Association Water International, Volume 25, Number 1, pp 127-138

[2] Faruqui, N., Biswas, A. and Bino, M. (2001): Water Management in Islam. IDRC Books, Ottawa, Canada 135 pp.

[3] WHO (World Health Organization) and UNICEF (United Nations International Children's Education Fund): 2000. Global Water Supply and Sanitation Assessment 2000 Report. WHO/UNICEF Joint Monitoring Programme for Water Supply and Sanitation, New York.

[4] EIS (Environmental Information System) UP (Uttar Pradesh): (2009) http://www.upenvis.nic.in/natural.htm

[5] Anonymous (1997), MIS Programme under National River Conservation Directorate, Ministry of Environment and Forests, Government of India, New Delhi, Vol 1, pp 16 - 17.

[6] IWACO (1996), Risk Assessment of the Yamuna River: Water Quality Monitoring Stations in India, Phase II, Government of India and Government of the Netherlands, Rotterdam, p15

[7] Pathak, S. P., Sanjay Kumar, P. W. Ramteke, R. C. Murthy, K. P. Singh, J. W. Bhattacherjee and P. K. Ray: (2004):Riverine pollution in some northern and north eastern states of India; Springer Netherlands ; Environmental Monitoring and Assessment; Volume 22, Number 3.

[8] FAO. (1992). Wastewater treatment and use in agriculture. M.B. Pescod. FAO Irrigation and Drainage Paper 47, FAO, Rome. 125 p.

[9] Vousta D, Grimanins A, Sammara C (1996). Trace elements in vegetable grown in industrial areas in relation to soil and air particulate matter. Environ. Pollut. 94 (3): $325-335$.

[10] Smith S.R. (1996); Agricultural Recycling of Sewage Sludge and the Environment. Biddles Ltd., Guildford. 